\title{
Isolasi dan identifikasi bakteri aerob yang dapat meyebabkan infeksi nosokomial di Ruang Bedah Mata RSUP Prof. Dr. R. D. Kondou Manado
}

\author{
${ }^{1}$ Nur Hasana M. N. A. \\ ${ }^{2}$ Fredine E. S. Rares \\ 3ohn Porotu'o
}

\author{
${ }^{1}$ Kandidat Skripsi Fakultas Kedokteran Universitas Sam Ratulangi Manado \\ ${ }^{2}$ Bagian Mikrobiologi Fakultas Kedokteran Universitas Sam Ratulangi Manado \\ Email: nurhasana136@yahoo.com
}

\begin{abstract}
Nosocomial infection, also called as the hospital-acquired infection, is infection that occurs in the hospital by bacterial pathogen originated from the hospital, and the occurence of infection 48 hours after hospitalization or patients who were treated longer. This study was aimed to determine types of bacteria that coud cause nosocomial infections in eye surgery room of Prof. Dr. R. D. Kandou General Hospital Manado. This was a descriptive prospective study. Samples were obtained from the floor, wall, operation table, medical instrument, and ambient air in the surgety room, then the samples were performed isolation and identification of the bacteria in the samples. The results showed that there were 6 types of bacteria, as follows: Bacillus sp, Enterobacter agglomerans, Staphylococccus sp, Enterobacter aerogenes, Lactobacillus sp, and Neisseria sp. The most common bacteria found in the samples was Enterobacter agglomerans as many as 9 samples (42. 9\%).
\end{abstract}

Keywords: aerobic bacteria, nosocomial infections, eye surgery room

\begin{abstract}
Abstrak: Infeksi Nosokomial atau disebut juga infeksi rumah sakit adalah infeksi yang terjadi di rumah sakit oleh kuman yang berasal dari rumah sakit, timbulnya infeksi sesudah 48 jam perawatan pada pasien rawat inap atau pada pasien yang di rawat lebih lama. Penelitian ini bertujuan untuk mengetahui jenis bakteri yang dapat menyebabkan infeksi nosokomial di ruang bedah mata RSUP Prof. Dr. R. D. Kandou Manado. Jenis penelitian ialah deskriptif prospektif. Sampel diperoleh lantai, dinding, meja operasi, alat medis, dan udara di ruang bedah mata RSUP Prof. Dr. R. D. Kandou Manado kemudian dilakukan isolasi dan identifikasi terhadap bakteri yang terdapat pada sampel. Hasil penelitian dari keseluruhan sampel didapatkan 6 bakteri secara umum yaitu: Bacillus sp, Enterobacter agglomerans, Staphylococccus sp, Enterobacter aerogenes, Lactobacillus sp, dan Neisseria sp. Bakteri terbanyak dari keseluruhan sampel yaitu Enterobacter agglomerans sebanyak 9 sampel (42,9\%).
\end{abstract}

Kata kunci: bakteri aerob, infeksi nosokomial, ruang bedah mata

Infeksi nosokomial adalah infeksi yang terjadi di rumah sakit oleh kuman yang berasal dari rumah sakit. ${ }^{1}$ Istilah infeksi nosokomial saat ini banyak dikenal dengan Hospital acquired Infection (HAIs), beberapa literatur juga kerap menggunakan istilah Health Care Associated Infections. Secara umum, WHO (World Health Organization) 2002, mendefinisikan infeksi nosokomial adalah infeksi yang didapat di rumah sakit,infeksi yang timbul atau terjadi sesudah 48 jam perawatan pada pasien rawat inap, infeksi yang terjadi pada pasien yang di rawat lebih lama dari masa inkubasi suatu penyakit. $^{2}$

Studi prevelensi pada tahun 1987 yang dilakukan dengan bantuan World Health Organization (WHO) pada 55 rumah sakit 
di 14 negara yang mewakili 4 wilayah WHO (Eropa, Mediterania Timur, Asia Tenggara, dan Pasifik Barat) mendapatkan 8,7\% pasien rumah sakit mengalami infeksi nosokomial. Dari hasil survei tersebut didapatkan frekuensi tertinggi infeksi nosokomial dilaporkan oleh rumah sakit di wilayah Mediterania Timur dan Asia Tenggara berturut-turut 11,8\% dan 10,0\%, sedangkan prevalensi di wilayah Eropa dan Pasifik Barat berturut-turut 7,7\% dan 9,0\%. ${ }^{3}$ Pada penelitian yang dilakukan oleh Wardana dan Acang pada tahun 1989 mendapatkan hasil observasi infeksi nosokomial insidensi $18,46 \%$ pada pasien yang dirawat di ruang rawat penyaki dalam RSUP M. Jamil, Padang. Pada penelitian lain pada tahun yang sama di RS. Hasan Sadikin Bandung didapatkan insidensi/ prevalensi infeksi nosokomial 17,24\% sedangkan di RSUD Dr. Sutomo adalah sebesar 9,85\%. ${ }^{4}$ Di Indonesia yaitu di 10 RSU pendidikan,infeksi nosokomial cukup tinggi yaitu 6-16\% dengan rata-rata 9,8\% pada tahun 2010. Infeksi nosokomial paling umum terjadi adalah infeksi luka operasi (ILO). Hasil penelitian terdahulu menunjukkan bahwa angka kejadian ILO pada rumah sakit di indonesia bervariasi antara 2-18\% dari keseluruhan prosedur pembedahan. ${ }^{5}$

Angka kejadian infeksi nosokomial di RSUP Prof. dr. R. D. Kandou Manado bulan Juli-Desember 2012, infeksi daerah luka operasi sebanyak 3,4\%, ISK sebanyak $2,7 \%$, infeksi aliran darah primer sebanyak 6,4\%, infeksi dekubitus sebanyak 0,7\%. ${ }^{6}$ Di Indonesia, angka kejadian infeksi nosokomial pasien rawat inap di bangsal bedah ialah pada rentang 5,8\%-6\% dan angka infeksi nosokimial pada luka bedah adalah 2,3\%-18,3\%. ${ }^{7}$ Persentase angka kejadian infeksi nosokomial di RSUD Dr. Pirngadi Medan pada tahun 2006 sebesar $32,16 \%$ yang mencakup infeksi yang disebabkan oleh penggunaan jarum infus $10 \%$, akibat tranfusi darah $10,16 \%$ dan luka operasi $12 \%{ }^{8}$ Selain itu juga diketahui adanya infeksi nosokomial di RSUP Dr. Sardjito pada tahun 2007 kejadian infeksi nosokomial mencapai $5,9 \%$ berasal dari kamar operasi, sedangkan di RSUP Adam Malik pada tahun 2010 angka prevalensi infeksi nosokomial luka operasi bersih pasca bedah adalah $5,6 \%{ }^{5}$

Kuman penyebab infeksi nosokomial yang tersering ialah Proteus sp, E. coli, S. aureus, dan Pseudomonas sp. Selain itu terdapat juga peningkatan infeksi nosokomial oleh kuman Enterocococus faecalis (Streptococcus faecalis). ${ }^{9}$

Faktor-faktor yang memberikan kontribusi terjadinya infeksi nosokomial antara lain: petugas yang berhubungan langsung dengan penderita, perawatan medis serta material medis yang digunakan untuk penderita, makanan dan minuman yang disajikan bagi penderita untuk memenuhi kebutuhan dasar sebagai upaya untuk pemulihan, ruangan atau bangsal tempat penderita di rawat, serta keluarga sebagai penunggu ataupun pengunjung. ${ }^{10}$ Faktor yang dapat menyebabkan infeksi nosokomial terutama pada pasien pasca operasi melibatkan peran peralatan bedah yang terkontaminasi dan faktor lain yang dapat memengaruhi adalah teknik pembedahan yang kurang baik atau tidak steril. Pasien yang sangat potensial terkena infeksi nosokomial ialah pasien pasca operasi, karena sangat rentan dengan berbagai infeksi sehubungan dengan ada luka operasi/pembedahan. ${ }^{11,12}$

Berdasarkan penjelasan bahwa infeksi nosokomial merupakan masalah penting bagi pasien yang dilakukan tindakan pembedahan/luka operasi maka penulis tertarik untuk melakukan penelitian diruang bedah mata RSUP. Prof. Dr. R. D. Kandou.

\section{METODE PENELITIAN}

Jenis penelitian ini ialah deskriptif prospektif. Penelitian ini dilaksanakan pada bulan November 2015-Januari 2016. Sampel diambil dari lantai, dinding, meja operasi, alat medis dan udara diruang Bedah Mata RSUP Prof. Dr. R. D. Kandou Manado kemudian diperiksa di Laboratorium Mikrobiologi Fakultas Kedokteran Universitas Sam Ratulangi Manado dengan pewarnaan Gram dan uji biokimia. 


\section{HASIL PENELITIAN}

Berdasarkan penelitian yang dilakukan di ruang Bedah Mata RSUP. Prof. Dr. R. D. Kandou Manado dengan sampel sebanyak 21 sampel ditemukan bakteri terbanyak Enterobacter agglomerans. Tabel 1 memperlihatkanb pengambilan sampel dilakukan pada 1 ruang bedah mata dimana terdiri dari 21 sampel yaitu 4 sampel dinding, 4 sampel lantai, 8 sampel udara (pagi-siang), 1 tempat tidur, 1 meja, 1 tempat duduk, 1 sandaran kepala, 1 tiang mikroskop.

Tabel 1. Sumber Sampel

\begin{tabular}{cc}
\hline Sumber Sampel & Jumlah \\
\hline Dinding & 4 \\
Lantai & 4 \\
Udara & 8 \\
Tempat Tidur & 1 \\
Meja & 1 \\
Tempat Duduk & 1 \\
Sandaran Kepala & 1 \\
Tiang Mikroskop & 1 \\
Total & 21 \\
\hline
\end{tabular}

Tabel 2 menunjukkan bahwa pada Nutrient Agar terjadi pertumbuhan koloni pada semua sampel, sedangkan pada Mac. Conkey Agar terjadi pertumbuhan koloni pada 14 sampel dan 7 sampel tidak ditemukan adanya pertumbuhan koloni.

Tabel 2. Distribusi Pertumbuhan Bakteri

\begin{tabular}{ccc}
\hline Perbenihan & $\begin{array}{c}\text { Nutrient } \\
\text { Agar }\end{array}$ & $\begin{array}{c}\text { Mac Conkey } \\
\text { Agar }\end{array}$ \\
\hline Ada & 21 & 14 \\
$\begin{array}{c}\text { Pertumbuhan } \\
\text { Tidak Ada }\end{array}$ & 0 & 7 \\
$\begin{array}{c}\text { Pertumbuhan } \\
\text { Total }\end{array}$ & 21 & 21 \\
\hline
\end{tabular}

Tabel 3 menunjukkan pada pemeriksaan Gram didapatkan bakteri terbanyak yaitu bakteri Gram negatif 11 sampel (52,4\%), kemudian bakteri Gram positif 8 sampel (38,1\%) dan bakteri Gram positif dan negatif sebanyak 2 sampel (9,5\%).

Tabel 4 menunjukkan dari 21 sampel terdapat 6 bakteri yaitu 3 bakteri gram negatif dan 3 bakteri gram positif. Dimana
3 bakteri gram negatif yaitu Enterobacter agglomerans total 9 sampel (42,9\%), Enterobacter aerogenes total 2 sampel (9,5\%), Neisseria, sp total 2 sampel (9,5\%). Tiga bakteri gram positif yaitu Bacillus, $s p$ total 4 sampel (19\%), Staphylococcus, sp total 1 sampel (4,8\%), Lactobacillus, $s p$ total 3 sampel (14,3\%).

Tabel 3. Hasil Pewarnaan Gram

\begin{tabular}{ccc}
\hline Pewarnaan Gram & Frekuensi & $\mathbf{( \% )}$ \\
\hline Gram Positif & 8 & 38,1 \\
Gram Negatif & 11 & 52,4 \\
Gram Positif \& & 2 & 9,5 \\
Negatif & & \\
Total & 21 & 100 \\
\hline
\end{tabular}

Tabel 4. Distribusi Pertumbuhan Bakteri Semua Sampel

\begin{tabular}{ccc}
\hline Bakteri & Frekuensi & $\mathbf{( \% )}$ \\
\hline Bacillus, $s p$ & 4 & 19 \\
Enterobacter & 9 & 42,9 \\
agglomerans & & \\
Staphylococcus, sp & 1 & 4,8 \\
Enterobacter & 2 & 9,5 \\
aerogenes & & \\
Lactobacillus, sp & 3 & 14,3 \\
Neisseria, $s p$ & 2 & 9,5 \\
Total & 21 & 100 \\
\hline
\end{tabular}

Pada Tabel 5 terdapat 2 jenis bakteri dari 4 sampel dengan perbandingan sampel dinding yang sama yaitu Enterobacter agglomerans total 2 sampel 50\% dan Bacillus, sp total 2 sampel 50\%.

Tabel 5. Pertumbuhan Bakteri Sampel Dinding

\begin{tabular}{ccc}
\hline Bakteri & Frekuensi & $\mathbf{( \% )}$ \\
\hline Enterobacter & 2 & 50 \\
agglomerasns & & \\
Bacillus, sp & 2 & 50 \\
Total & 4 & 100 \\
\hline
\end{tabular}

Tabel 6 menunjukkan 3 jenis bakteri dari 4 sampel yang terdiri dari Lactobacillus, sp total 2 sampel (50\%), Enterobacter agglomerans total 1 sampel (25\%), Enterobacter aerogenes total 1 sampel (25\%). 
Tabel 6. Pertumbuhan Bakteri Sampel Lantai

\begin{tabular}{ccc}
\hline Bakteri & Frekuensi & $\mathbf{( \% )}$ \\
\hline Lactobacillus, sp & 2 & 50 \\
Enterobacter & 1 & 25 \\
agglomerans & & \\
$\begin{array}{c}\text { Enterobacter } \\
\text { aerogenes } \\
\text { Total }\end{array}$ & 1 & 25 \\
\hline
\end{tabular}

Tabel 7 menunjukkan 4 jenis bakteri dari 8 sampel yaitu Bacillus, sp total 1 sampel (12,5\%), Enterobacter agglomerans total 5 sampel (62,5\%), Staphylococcus, $s p$ total 1 sampel (12,5\%), Enterobacter aerogenes total 1 sampel (12\%).

Tabel 7. Pertumbuhan Bakteri Pada Udara

\begin{tabular}{ccc}
\hline Bakteri & Frekuensi & \% \\
\hline Bacillus, sp & 1 & 12,5 \\
Enterobacter & 5 & 62,5 \\
agglomerans & & \\
Staphylococcus, sp & 1 & 12,5 \\
Enterobacter & 1 & 12,5 \\
aerogenes & & \\
Total & 8 & 100 \\
\hline
\end{tabular}

Tabel 8 menunjukkan 4 jenis bakteri dari 5 sampel yaitu Neisseria, sp total 2 sampel (40\%), Lactobacillus, sp total 1 sampel (20\%), Enterobacter agglomerans total 1 sampel (20\%), Bacillus, sp total 1 sampel (20\%).

Tabel 8. Pertumbuhan Bakteri Pada Perabotan atau Peralatan Medis

\begin{tabular}{ccc}
\hline Bakteri & Frekuensi & $\mathbf{\%}$ \\
\hline Neisseria, $s p$ & 1 & 20 \\
Neisseria, $s p$ & 1 & 20 \\
Lactobacillus, $s p$ & 1 & 20 \\
Enterobacter & 1 & 20 \\
agglomerans & & \\
Bacillus, $s p$ & 1 & 20 \\
Total & 5 & 100 \\
\hline
\end{tabular}

\section{BAHASAN}

Penelitian ini dilakukan pada lantai, dinding, udara, tempat tidur, meja, tempat duduk, sandaran kepala dan tiang mikroskop diruang bedah mata dengan sampel sebanyak 21 sampel. Identifikasi sampel dilakukan di Laboratorium Mikrobiologi Fakultas Kedokteran Unsrat Manado yaitu pewarnaan Gram dan uji biokimia. Pada penelitian ini ditemukan 6 bakteri secara umum yaitu Bacillus sp, Enterobacter agglomerans, Staphylococcus sp, Enterobacter aerogenes, Lactobacillus sp, dan Neisseria sp.

Dari semua sampel ditemukan 1 sampel yang memiliki perbandingan yang sama yaitu pada dinding, dari 4 sampel menunjukkan 2 bakteri yaitu Enterobacter agglomerans sebanyak 2 sampel (50\%) dan Bacillus sp. sebanyak 2 sampel (50\%), pada sampel lantai ditemukan bakteri tebanyak yaitu Lactobacillus sp. sebanyak 2 sampel 50\%, pada sampel udara ditemukan bakteri terbanyak yaitu Enterobacter agglomerans sebanyak 5 sampel (62,5\%) dan pada pemeriksaan tempat duduk, tempat tidur, meja, sandaran kepala dan tiang mikroskop hanya ditemukan masing-masing 1 jenis bakteri yaitu secara berurut Enterobacter agglomerans, Neisseria sp, Neisseria sp, Lactobacillus sp dan Bacillus sp.

Penelitian yang dilakukan Saleh ${ }^{19}$, tentang pola bakteri aerob penyebab infeksi nosokomial pada ruangan neonatal intensive care unit (NICU) BLU RSUP Prof. Dr. R. D. Kandou Manado mendapatkan bakteri terbanyak ialah Bacillus subtilis. Berdasarkan penelitian yang dilakukan oleh Mardaneh et al. ${ }^{20}$ bakteri Enterobacter agglomerans ditemukan pada isolasi dan identifikasi bubuk susu formula di NICU di Iran. Sedangkan pada penelitian ini di dapatkan bakteri Enterobacter agglomerans pada sampel udara. Penelitian Saleh ${ }^{19}$ mendapatkan Lactobacillus pada sampel dinding dan suction, sampel pada meja yaitu klebsiella pneumoniae sedangkan pada penelitian ini ditemukan 2 bakteri terbanyak di dinding yaitu Enterobacter agglomerans dan Bacillu, sp, dan pada sampel meja ditemukan bakteri Neisseria sp.

Pada penelitian yang dilakukan Sofyan $^{21}$ pada 2 kamar operasi CITO di RSUP Prof. R. D. Kandou ditemukan kuman terbanyak yaitu Bacillus subtillis 
dan pada sampel lantai ditemukan bakteri terbanyak yaitu kokus Gram negatif dan Bacillus subtilis sedangkan pada penelitian saya ditemukan bakteri terbanyak yaitu Enterobacter agglomerans dan pada sampel lantai ditemukan Lactobacillus sp.

Ditemukan bakteri Gram negatif dalam jumlah yang tidak sedikit dikarenakan redahnya sterilitas di rumah sakit. Bakteribakteri yang menyebabkan infeksi nosokomial sering ditemukan hidup pada permukaan kulit tangan manusia dan memperbanyak koloninya pada suhu yang tinggi. Bakteri batang gram negatif atau golongan Enterobacteriaceae dapat menempel pada tangan tenaga kesehatan, peralatan medis dan udara. ${ }^{19}$

Ruangan bedah mata di rumah sakit Prof. Dr. R. D, Kandou dibersihkan setiap hari. Pembersihan ruangan misalnya menyapu dan mengepel dilakukan oleh cleaning service sedangkan untuk pembersihan semua alat yang digunakan untuk pembedahan dalam ruang bedah mata dibersihkan dan disterilkan oleh perawat menggunakan ultraviolet dengan besarnya sinar UV 1-5 watt/m² ruangan.

\section{SIMPULAN}

Dari hasil penelitian dan bahasan dapat disimpulkan bahwa dari 30 sampel yang diperiksa didapatkan 6 jenis bakteri yaitu Bacillus sp, Enterobacter agglomerans, Staphylococcus sp, Enterobacter aerogenes, Lactobasillus sp, dan Neisseria, sp. Enterobacter agglomerans merupakan bakteri terbanyak yang ditemukan.

\section{SARAN}

1. Sebaiknya penelitian ini dilanjutkan dengan uji sensitivitas terhadap antibiotik.

2. Diperlukan kegiatan uji sterilisasi secara berkala.

3. Tenaga medis diharapkan memperhatikan kebersihan dan sanitasi diri sendiri untuk mencegah terjadinya infeksi silang.

\section{DAFTAR PUSTAKA}

1. Staf pengajar Fakultas Kedokteran
Universitas Indonesia. Mikrobiologi Kedokteran. Edisi revisi. Tangerang: Binarupa Aksara; p. 75-76.

2. Widodo J, Irwanto R. Infeksi nosocomial. In: Setiati S, Alwi I, Sudoyo A, Simadibrata MK, Setiyohadi B, Syam AF. Ilmu Penyakit Dalam (6th ed). Jakarta: InternaPublishing, 2014; p. 682-6.

3. Introduction. In: Ducel G, Fabry J, Nicolle L, penyunting. Prevention of hospitalacquired infections, apractical guide (2nd ed). Malta: World Health Organization, 2002; p. 1-3. [cited 21 Januari 2009]. Available from: www.who.int/csr/resources/publicatio ns/drugresist/en/whocdscsreph200212 .pdf

4. Ginting $Y$, Panjaitan B. Pencegahan Infeksi Nosokomial. Makalah Seminar Ilmiah Tahunan II Bagian Ilmu Penyakit Dalam FK USU Medan 2001. Available from: repository.usu.ac.id/.../1/pan-jul2006\%20(8).pdf]

5. Jeyamohan, D. Angka prevalensi infeksi nosokomial pada pasien luka operasi pasca bedah di Bagian Bedah di Rumah Sakit Umum Pusat Haji Adam Malik, Medan dari bulan April sampai September 2010. Available from:

http://repository.usu.ac.id/bitstream/1 23456789/21521/7/Cover.pdf

6. Rotti G. Hubungan fungsi manajemen kepala ruangan dengan pelaksanaan pencegahan dan pengendalian infeksi di ruang rawat inap rumah sakit umum pusat Prof R. D. Kandou Manado. Jurnal Fakultas Kedokteran Universitas Hasanudin. 2014. Available from: http://pasca.unhas.ac.id/jurnal/files/0b 60c7003cded01d999cf249cb3c68f6.p df)

7. Hermawan AG. 2007. The role of cefepime: Empirical treatment in critical illness. Available from: http://www.DexaMedia/publication_u pload07064306550001180931345De xaMedia/edisi/april-jun2007.pdf

8. Nasution DE. 2008. Pengaruh motivasi perawat terhadap tindakan perawatan pada pasien pasca bedah di Ruang Rawat Inap Rumah Sakit Umum Dr. 
Pirngadi Kota Medan. Available from:

http://www.repository.usu.ac.id/bitstr eam/123456789/6702/1/09E00173.pd $\mathrm{f}$

9. Sudoyo AW, Setiyohadi B, Alwi I, Setiadi S, Ilmu Penyakit Dalam (5th ed). Jakarta: 2009; p. 2907-8.

10.Darmadi. Infeksi nosokomial problematika dan pengendaliannya. Jakarta: Salemba Medika, 2008.

11.Infeksi nosokomial masalah besar, Suara Merdeka, Rabu, 18 juli 2001.

12.Sjamsuhidajat R, Jong WD. Buku Ajar Ilmu Bedah. Jakarta : EGC, 2005.

13.Harry U. Infeksi nosokomial. Desember 2006. [cited at 2015 Okt 21]. Available from: http://klikharry.com/2006/12/21/infek si-nosokomial/

14.Unimus Semarang. Available from: http://digilib.unimus.ac.id/files/disk1/ 105/jtptunimus-gdl-ratikaprik-52312-bab2.pdf

15.Smith-Keary PF. Genetic Elements in Escherichia coli. London: Macmillan Molecular Biology Series, 1988; p. 19, 49-54.

16.Jawetz E, Melnick JL, Adelberg EA, Brooks GF, Butel JS, Ornston LN. Mikrobiologi Kedokteran (20 ed). San Fransisco: University of California. 1995.
17.Warsa UC. Staphylococcus. In: Buku Ajar Mikrobiologi Kedokteran. Edisi Revisi. Jakarta: Binarupa Aksara, 1994; p. 103-110.

18.Ryan KJ, Champoux JJ, Falkow S, Plonde JJ, Drew WL, Neidhardt FC, Roy CG. Medical Microbiology An Introduction to Infectious Diseases (3rd ed). Connecticut: Appleton \& Lange, 1994; p. 254.

19.Ilyas S, Yulianti SR. Ilmu Penyakit Mata (5th ed). Jakarta: Penerbit FKUI; p. 91-104.

20.Saleh M, Rares FES, Soeliongan S. Pola bakteri aerob penyebab infeksi nosokomial pada Ruangan Neonatal Intensive Care Unit (Nicu) BLU RSUP Prof. Dr. R. D Kandou Manado. eBm. 2015;3:239.

21.Mardaneh J, Dallal MM. Isolation, identification and antimicrobial susceptibility of Pantoea (Enterobacter) agglomerans isolated from consumed powdered infant formula milk (PIF) in NICU ward. Iran J Microbiol. 2013;5(3):263-7.

22.Sofyan AF, Homenta H, Rares F. Pola aakteri aerob yang berpotensi menyebabkan infeksi nosokomial di kamar operasi BLU RSUP Prof. Dr. R. D. Kandou Manado. eBm. 2015;3(1). 